Check for updates

Portsmouth

Cite this as: BMJ 2021;375:n2991

http://dx.doi.org/10.1136/bmj.n2991

Published: 02 December 2021

\section{World Health Organization to begin negotiating international pandemic treaty}

Luke Taylor

World Health Organization states agreed on 1 December to begin negotiating an international agreement on how countries must prevent, prepare for, and react to pandemics.

The decision was made by WHO's 194 member states, who convened in Geneva for the second ever special session of the World Health Assembly, and what senior WHO officials said was an inflection point in international public health.

The agreement is "a cause for celebration and cause for hope, which we will need," said WHO's director general, Tedros Adhanom Ghebreyesus. "Let it be said, decades from now when each of us is nothing more than photographs and memories, that we left the world a healthier, safer, fairer place than we found it."

Member states have agreed to a timeline which could lead to a legally binding treaty tackling the global inequities and political divisions which have facilitated covid-19's spread and the more than $\mathbf{5 . 2}$ million related deaths. It could oblige states to share vaccines and medical equipment in the case of a future pandemic as well as information on emerging health threats. ${ }^{1}$

The special session was convened after several WHO members called for an international legal framework in May in order to ensure countries respond to future health crises better than they did to covid-19. ${ }^{2}$

It will take years to draw up any convention and it is unclear exactly what it will cover and how much global authority it will hold, with countries pushing and pulling in different directions.

Low and middle income countries have focused on the need to tackle the global inequity of vaccines, tests, and other health resources, which they say are prolonging the pandemic. Some $80 \%$ of the world's covid-19 vaccines have gone to wealthy G20 nations and only $0.6 \%$ have reached low income countries, according to $\mathrm{WHO}^{3}$

Wealthier nations have stressed the need for better information sharing-most importantly on new outbreaks of infectious diseases. WHO says that China has still not shared some of its early data that could help identify the origin of covid-19. 4

While the European Union and at least 70 other countries are pushing for a legally binding treaty, Brazil, the US, and others want a softer agreement.

Any accord will likely draw heavily on the International Health Regulations (IHR), a legal framework revised in 2005 to define the obligations for countries in the case of cross-border public health threats. ${ }^{5}$ It should focus on delivering key IHR pledges that have not been realised, said David Heymann, professor of infectious disease epidemiology at the London School of Hygiene and Tropical Medicine.

In particular, it should develop the ability of all countries to detect new health threats independently, react to them quickly, and share information in real time. "Any treaty should emphasise the need to strengthen core capacities and not build global mechanisms that exclude country capacity development-an example being a global surveillance system for covid-19," Heymann said.

As well as a consensus between nearly 200 nations, any agreement will require financing. And to be effective in practice, it will need a strong international legal framework that rewards good public health behaviour and disincentives bad behaviour with sanctions, Andrés Constantin, adjunct professor of law at the O'Neill Institute for National and Global Health Law at Georgetown University, said.

Though IHR stipulate that governments should not impose travel bans or close borders, governments have closed frontiers and grounded flights in efforts to contain the nascent omicron variant, Constantin said. "We have these treaties, and we can have a new one, but unless you change the incentives for story will be the same," he said.

The international body formed to negotiate the treaty will hold its first meeting before 1 March 2022 to agree timelines and its second by 1 August 2022 to discuss progress on a working draft. It will simultaneously hold public hearings to inform its decisions, deliver a progress report to the 76th World Health Assembly in 2023, and submit an agreement for consideration

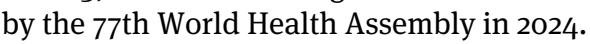

“There is still a long road ahead,” Ghebreyesus said.

WHO reaches draft consensus on future pandemic treaty. Reuters. www.reuters.com/business/healthcare-pharmaceuticals/who-reaches-draftconsensus-future-pandemic-treaty-2021-11-28.

2 Is a WHO pandemic treaty set to fail? Reuters. https://news.trust.org/item/20211130170554-pn8gh.

WHO director-general's opening remarks at the special session of the World Health Assembly. www.who.int/director-general/speeches/detail/who-director-general-s-opening-remarks-at-the-special-session-of-the-worldhealth-assembly-29-november-2021.

4 The WHO is seeking a new treaty on handling future pandemics. It could be a hard sell. NPR. www.npr.org/sections/goatsandsoda/2021/11/28/1059025751/who-seeks-a-new-treaty-on-handling-futurepandemics-it-could-be-a-hard-sell?t=1638372071963.

WHO. The World Together: Establishment of an intergovernmental negotiating body to strengthen pandemic prevention, preparedness and response. https://apps.who.int/gb/ebwha/pdf_files/WHASSA2/SSA2_CONF1Rev1-en.pdf. governments to comply with such obligations, the 